\title{
Peran Media Massa Inggris dan Jerman dalam Menginformasikan Pandemi COVID-19
}

\author{
Rizky Anggraini ${ }^{1}$, Henny Saptatia ${ }^{2^{*}}$ \\ ${ }^{1,2}$ Universitas Indonesia \\ *Email: henny.saptatia@ui.ac.id
}

Disetujui : 27 Januari 2021
Diterbitkan : 19 Februari 2021

\begin{abstract}
Abstrak
Pandemi COVID-19 yang melanda berbagai belahan dunia menghasilkan berita yang intens memenuhi ruang publik, termasuk media massa di Inggris dan Jerman. Peran media massa digital arus utama tidak dapat dianggap remeh dalam penyebaran informasi COVID-19 kepada masyarakat. Penelitian ini bertujuan untuk mengetahui peran media massa di Inggris dan Jerman dalam memberitakan penyebaran COVID-19 dan menginformasikan krisis kesehatan yang terjadi di dua negara tersebut. Penelitian ini menggunakan teori framing dan teori tanggung jawab sosial media. Jerman disebut sebagai negara dengan penanganan pandemi yang baik sejak awal kemunculan COVID-19 di Eropa Barat, sedangkan Inggris disebut terlambat dalam menangani pandemi COVID-19. Objek penelitian yang dipilih adalah platform berita online Inggris dan Jerman yang masing-masing memiliki karakter yang berbeda. Temuan penelitian ini adalah terdapat perbedaan bingkai dominan pemberitaan media massa Inggris dan Jerman. Media Inggris lebih menekankan perubahan perilaku sosial masyarakat dalam menangani pandemi COVID-19 dengan dominasi artikel-artikel mengenai protokol kesehatan dan artikel medis. Sedangkan media Jerman lebih menekankan dampak pandemi terhadap perekonomian negara dan dampak kesehatan akibat pandemi COVID-19 dalam pemberitaannya.
\end{abstract}

Kata Kunci: Media massa, Inggris, Jerman, Krisis kesehatan, Covid-19

\begin{abstract}
The COVID-19 pandemic that has hit various parts of the world has resulted in intense news filling public spaces, including the mass media in the UK and Germany. The role of mainstream digital mass media cannot be underestimated in disseminating COVID-19 information to the public. This study aims to determine the role of the mass media in Britain and Germany in reporting the spread of COVID-19 and informing the health crisis that has occurred in these two countries. This research uses framing theory and social media responsibility theory. Germany is said to be a country with a good handling of the pandemic since the beginning of the emergence of COVID-19 in Western Europe, while Britain is said to be late in dealing with the COVID-19 pandemic. The research object chosen was the English and German online news platforms, each of which has a different character. The finding of this study is that there are differences in the dominant frame of reporting in the British and German mass media. British media places more emphasis on changing people's social behavior in dealing with the COVID-19 pandemic with the dominance of articles on health protocols and medical articles. Meanwhile, the German media emphasizes the impact of the pandemic on the country's economy and the health effects of the COVID-19 pandemic in its reporting.
\end{abstract}

Keywords: Mass media, Britain, Germany, Health crisis, COVID-19 


\section{PENDAHULUAN}

Pada 31 Desember 2019 World Health Organization (WHO) mengumumkan kasus pneumonia yang muncul di Wuhan, China, disebabkan oleh virus novel corona yakni virus baru yang sejenis virus SARS dan MERS. Coronaviruses adalah keluarga besar virus yang menyebabkan penyakit mulai dari flu biasa hingga penyakit yang lebih parah. Virus ini adalah virus jenis baru yang belum diidentifikasi sebelumnya pada manusia (World Health Organization, 2020). Kasus pertama yang ditemukan di luar China teridentifikasi pada 13 Januari 2020 di Bangkok, Thailand. WHO pada 11 Februari 2020 menamakan penyakit yang menyebar keberbagai belahan dunia yang disebabkan oleh virus SARS-CoV-2 sebagai COVID-19. Pada 2 Maret 2020, 67 provinsi di daratan China melaporkan 8.565 kasus dengan kematian mencapai 132 orang. Virus ini kemudian menyebar ke berbagai belahan dunia, dan pada 11 Maret 2020 saat kasus dikonfirmasi telah menyebar ke 114 negara dengan kasus mencapai 118.000, WHO lalu menetapkan COVID-19 sebagai pandemi global. Di Inggris kasus COVID-19 ini pertama kali ditemukan pada akhir Januari 2020. Kemudian, pada 16 Maret 2020, Perdana Menteri Inggris Boris Johnson mengumumkan pembatasan fisik bagi masyarakat Inggris (Mahase, 2020)

Jerman menjadi negara termasuk lima terbesar kasus positif dengan jumlah 139.897 jiwa namun memiliki jumlah kematian dengan presentasi yang kecil sebesar 4.294 jiwa (WHO, 2020). Pada 15 Maret 2020, 16 negara bagian di Jerman menutup sekolah dan melarang pertemuan. Pada 22 Maret 2020, setelah berkonsultasi dengan para pemimpin negara bagian, Kanselir Jerman Angela Merkel mengumumkan aturan yang melarang lebih dari dua orang yang tinggal di rumah yang berbeda berada di luar bersama-sama (Stafford, 2020).

Krisis kesehatan terkait pandemi yang muncul menghasilkan spekulasi yang intens dan berita yang memenuhi ruang publik di Eropa, termasuk di Inggris dan Jerman. Peran internet dan media pers arus utama tidak dapat dianggap remeh dalam hal penyebaran informasi mengenai COVID-19 kepada masyarakat, di samping komunikasi yang dikeluarkan oleh saluran resmi WHO (Leach \& Dry, 2010). Kemampuan media massa untuk membuat pesan yang menjangkau banyak orang memungkinkan media massa dapat mengedukasi audiens tentang bagaimana penyakit tersebut dapat dihindari dan dicegah (Abraham, 2007). Pemberitaan media efektif dalam menahan penyebaran darurat pandemi pada tahap awal, berdasarkan penelitian keterkaitan antara data dari media dan data dari kasus infeksi. Laporan media massa dan edukasi berpotensi mempengaruhi kesadaran masyarakat, dengan demikian dapat memodifikasi perilaku masyarakat selama wabah penyakit menular (Pieri, 2019).

Dalam konteks ini media mempunyai peran penting sebagai alat komunikasi antara pemerintah maupun tenaga kesehatan kepada masyarakat, dengan memberikan informasi terbaru terkait penanganan maupun pencegahan. Fungsi pengawasan dalam media juga berperan untuk penentuan agenda politik terutama berkaitan dengan pengawasan kebijakan publik yang diambil pemerintah Jerman dan Inggris dalam menangani COVID-19 ini (Zhou et al., 2020).

Penelitian ini tentang bagaimana media massa Inggris dan Jerman memiliki peran dalam menginformasikan penyebaran COVID-19 dan darurat kesehatan di kedua negara 
tersebut akibat COVID-19. Tujuan penelitian ini untuk meneliti peran media massa dalam menangani pandemi COVID-19, bagaimana media massa turut bertanggung jawab dalam menekan penyebaran COVID-19, sebagaimana pesan komunikasi dalam fungsi media menjadi kunci dalam menanggapi penanggulangan kesehatan masyarakat karena dapat mempengaruhi perilaku publik.

Menurut Hallin dan Manchini (2004) Inggris dan Jerman memiliki karakter media massa yang berbeda. Pers di Jerman memiliki karakteristik media yang plural, kebebasan pers di Jerman juga dijamin oleh undang-undang, meskipun demikian pers di Jerman masih rentan terhadap intervensi baik dari partai politik maupun pemerintah. Sedangkan media massa di Inggris memiliki karakter pers yang komersil. Karakter pers yang komersil memungkinkan suatu pers bersifat independen dan terbebas dari dominasi kepentingan politik negara maupun partai, akan tetapi hal tersebut tidak berlaku di Inggris. Konsep 'paralelisme pers' dikembangkan di Inggris, terdapat kecenderungan pers di Inggris yang mencerminkan perpecahan dalam partai politik (Fletcher \& Jenkins, 2019). Objek penelitian yang dipilih adalah platform berita online arus utama Inggris yakni BBC dan The Guardian, kedua media massa tersebut memiliki pembaca yang cukup banyak di Inggris. Sedangkan media massa dari Jerman adalah Deutche Welle (DW) dan Bild.

Penelitian ini menggunakan teori framing. Media membuat bingkai berita dengan memperkenalkan item berita dengan kontekstualisasi yang didefinisikan ulang dan sempit. Bingkai dapat dirancang untuk meningkatkan pemahaman atau digunakan sebagai jalan pintas kognitif untuk menghubungkan cerita dengan gambaran yang lebih besar. Framing dapat ditafsirkan sebagai bentuk tingkat kedua dari agenda setting sebuah media massa mereka tidak hanya memberi tahu penonton apa yang harus dipikirkan (teori pengaturan agenda), tetapi juga bagaimana mereka bisa memikirkan masalah tersebut (Entmant, 1993; Entmant, 2007).

Teori kedua adalah tanggungjawab sosial pers. Menurut Theodore Peterson perbedaan esensial media dalam konsep atau teori tanggung jawab sosial adalah, media must assume obligation of social responsibility; and if they do not, someone must see they do (Siebert, Peterson, \& Schramm, 1963). Prinsip yang mendasari teori tanggung jawab sosial pers adalah bahwa pers harus bebas untuk melakukan fungsi-fungsi yang diberikan oleh teori libertarian untuk melakukan kebebasan, tetapi kebebasan ini harus dilaksanakan dengan tanggung jawab (Okunna \& Omenugha, 2012). Jika media gagal memenuhi tanggung jawab mereka kepada masyarakat, teori tanggung jawab sosial berpendapat bahwa pemerintah harus mendorong media untuk patuh dengan cara mengendalikannya.

Terkait teori itu, Dominick (2009) berpendapat bahwa pers memiliki hak untuk mengkritik pemerintah dan lembaga-lembaga lain, tetapi ia juga memiliki tanggung jawab untuk memelihara demokrasi dengan memberi tahu publik dengan benar dengan menanggapi kebutuhan dan kepentingan masyarakat. Dari penjelasan tersebut, dapat disimpulkan bahwa prinsip-prinsip dasar teori tanggung jawab sosial media adalah media memiliki kebebasan pers namun harus dilaksanakan dengan tanggung jawab penuh demi kepentingan masyarakat (Andersson et al., 2002). Tujuan penelitian ini adalah untuk mengetahui peran media massa pada kedua negara memiliki tanggung jawab sosial terhadap pandemi COVID-19 di Inggris 
dan Jerman. Identifikasi tema dan bingkai diamati untuk memahami peran media dalam kaitannya dengan pemberitaan COVID-19.

\section{METODOLOGI PENELITIAN}

Penelitian ini menggunakan pendekatan kualitatif dengan fokus kajian analisis framing media massa menggunakan model analisis Entman dan menggunakan teori tanggung jawab sosial media. Menurut Entmant, frame atau bingkai adalah untuk memilih beberapa aspek dari realitas yang dirasakan dan membuatnya lebih menonjol dalam teks yang berkomunikasi sedemikian rupa untuk mempromosikan definisi masalah tertentu, interpretasi kausal, evaluasi moral, dan/ atau rekomendasi pengobatan. Bingkai bisa berupa teks, pemilihan judul dan penempatan berita serta penggunaan gambar dalam sebuah berita (Entman, 1993). Dampak bingkai media pada persepsi publik dan tanggapan terhadap masalah atau isu yang sedang terjadi baik dari karakter permasalahan, penyebab, dan konsekuensi dari fenomena apa pun menjadi sangat berbeda seiring dengan bentuk narasi yang dibuat, ditampilkan, dan yang ditekankan dalam sebuah narasi berita.

Berdasarkan teori framing, peneliti melakukan analisis terhadap liputan media massa online di Inggris untuk mengidentifikasi bingkai berita yang diedarkan melalui media arus utama Inggris yakni The Guardian dan BBC ke arena publik tentang ancaman yang ditimbulkan oleh COVID-19 dan juga media massa Jerman yakni Bild dan DW. Teori framing digunakan melihat bagaimana media massa di kedua negara ini menonjolkan bingkai dalam pemberitaan mengenai pandemi COVID-19. Hasil analisis disajikan untuk mengungkapkan bagaimana narasi dan bingkai dominan ini memungkinkan penilaian tertentu dibuat untuk menjalankan fungsi tanggung jawab sosial pers dalam menekan penyebaran pandemi COVID-19 yang berbeda di kedua negara tersebut, sehingga berita tersebut mempengaruhi kebijakan pemerintah dan mengubah perilaku masyarakat dalam menghadapi pandemi COVID-19.

\begin{tabular}{|c|c|c|c|c|c|c|}
\hline n & Cancordanes & Set Tag & word $*$ & \multicolumn{3}{|c|}{ Sent Sert Para Para Heat Heat Sect Sect } \\
\hline & Icoronavirus-have-i-already-had-covid-19 Covid-19 symptoms, when they occur, & & 19 & $28 \%$ & $02 \%$ & $02 \%$ \\
\hline 2 & 1 Jul 202017.45 BST Shares 962 Cond 19 symploms vary widely, and & & 63 & 268 & $06 \%$ & $06 \%$ \\
\hline 3 & We might become blase about Covid-19 deaths when life resumes & & 1.804 & 7023 & $090^{\circ}$ & $090^{\prime \prime}$ \\
\hline 4 & help slow the virus. The fight against Covid-19 is being waged street by & & 678 & 3113 & 082 & $082^{\prime \prime}$ \\
\hline 5 & com/business/2020/sep/25/ & & 42 & 051 & $06 \%$ & $06 \%$ \\
\hline 6 & were suspected rather than confirmed Covid-19 cases. But this study does at & & 594 & 2692 & 071 & $071^{\prime \prime}$ \\
\hline ? & theguardian com/world/2020/sep/25/ & & 15 & 029 & $02 \%$ & $02 \%$ \\
\hline 8 & number of people testing positive for Covid-19 in all age groups, with the & & 355 & 1321 & $058^{\prime}$ & $058^{\prime}$ \\
\hline 9 & people are testing positive for Covid-19 a second time. Most & & 846 & 3983 & $088^{\prime}$ & $088^{\prime \prime}$ \\
\hline 10 & that most people who recovered from Covid-19 without going into hospital & & 405 & 2058 & $020^{\prime}$ & $020^{\prime \prime}$ \\
\hline 11 & an estimated 103,600 people had Cond-19 between 13 and 19 & & 311 & 1168 & 051 & $051^{\prime}$ \\
\hline 12 & theguardian com/global/2020/apr/13/coronavirus-have-i-already-had-covid-19 & & 18 & $27 \%$ & $02 \%$ & $02 \%$ \\
\hline 13 & way to know whether someone has had Covid-19 in the past? Dr William & & 117 & 480 & 012 & $012^{\prime \prime}$ \\
\hline 14 & , then we are doomed to have Covid become endemic, an infection & & 1.308 & 5664 & $066^{\prime}$ & $066^{\prime \prime}$ \\
\hline 15 & 0:42 Aerosol particles suspended in Covid transmission testing lab a€' & & 269 & $66 \%$ & $030^{\prime}$ & $030^{\prime \prime}$ \\
\hline 16 & the role of airborne transmission in Covid-19.Ae Advertisement For & & 359 & 682 & $040^{\circ}$ & $040^{\prime}$ \\
\hline 17 & UK scientists begin study of how long Covid can survive in the air 25 sep 20 & & 8 & 017 & $01 \%$ & $01 \%$ \\
\hline 18 & theguardian com/world $/ 2020 / \mathrm{sep} / 25 /$ & & 17 & 039 & $02 \%$ & $02 \%$ \\
\hline 19 & or suspected childhood cases of Covid-19. Just over half of the children & & 526 & 2210 & $063^{\prime}$ & $063^{\prime \prime}$ \\
\hline 20 & years. afecelt will be harder to get nd of Covid than smallpox,af says Brilliant. & & 1.341 & 5696 & 067 & $067^{\prime \prime}$ \\
\hline 21 & doctor, Li Wenliang, died of Covid-19. The Chinese Communist & & 340 & 1010 & $078^{\prime}$ & $078^{\prime \prime}$ \\
\hline 22 & judge is approximately $5 \%$ below its pre-Covid peak af $\epsilon^{2}$ over the next three & & 344 & 694 & 052 & $052^{\prime}$ \\
\hline 23 & recently analysed blood from recovered Covid -19 patients and found that levels & & 359 & 1928 & $018^{\prime}$ & $018^{\prime \prime}$ \\
\hline 24 & af Until now, it has been expected that Covid-19 is predominantly transmitted & & 174 & 287 & 019 & $019^{\prime} / v$ \\
\hline
\end{tabular}

Gambar 1. Condordance Wordsmith Media Massa 
Semua artikel yang menyebutkan tentang COVID-19 dikumpulkan dari dua media massa yang dipilih untuk dianalisis dengan menggunakan tools Wordsmith, untuk diperoleh framing apa saja yang dominan diberitakan oleh media massa. Tahapan penelitian menggunakan aplikasi Wordsmith untuk mencari dominan kata dalam pemberitaan media massa terhadap pemberitaan COVID-19. Penulis mengumpulkan sampel sebayak 210 artikel dalam periode Januari sampai dengan Mei 2020 dari media massa Inggris BBC dan The Guardian dengan kata kunci coronaviruses. Melalui Wordsmith, penulis bisa mengumpulkan kata apa saja yang diulang dalam pemberitaan, dominan tema apa saja yang muncul sehingga dapat dilihat bagaimana media massa memberitakan COVID-19 dan melihat perannya dalam membantu mengurangi penyebaran virus COVID-19.

Kronologi dari kata kunci “COVID-19” pada periode Desember 2019 sampai Mei 2020 di media Inggris sebagai adalah berikut:

- Munculnya kasus pneumonia yang tidak di ketahui di China

- WHO menyebut kasus pneumonia tersebut wabah COVID-19, negara di dunia diminta waspada.

- Ditemukannya kasus COVID-19 pertama di Inggris

- Perdana Menteri Inggris mengatakan COVID-19 tidak berbahaya

- Maret 2020 kasus kematian pertama di Inggris

- Inggris mulai memasuki tahap physical distancing

- Pemerintah UK mengumumkan menutup perbatasan

- Pada Mei 2020 pemerintah Inggris mulai melonggarkan lockdown, warga berbondongbondong berjemur di Taman.

Selanjutnya untuk Jerman berdasarkan kronologi dari keyword "COVID-19" dalam pemberitaan media massa Jerman, diperoleh kronologi sebagai berikut:

- Kasus pertama COVID-19 ditemukan pada 27 Januari 2020, pemerintah Jerman membuat Tim Penanganan COVID-19.

- 24 Februari 2020 menteri kesehatan Jerman membatalkan semua event besar setelah kematian pertama akibat COVID-19.

- 22 Maret 2020 kanselir Jerman mengumumkan lockdown.

- 15 April 2020 Jerman sudah mulai mengembangkan vaksin COVID-19.

- 22 April 2020 Jerman mengumumkan peraturan wajib mengenakan masker di tempat umum karena sebagian sekolah di Jerman sudah mulai dibuka.

- 6 Mei 2020 Kanselir Jerman Angela Merkel mengumumkan gelombang pertama melawan pandemi sukses dilakukan.

- 13 Mei 2020 lockdown sudah mulai dilonggarkan seiring dengan menurunnya kasus, Bundesliga Jerman dibuka kembali.

\section{HASIL DAN PEMBAHASAN}

Hasil dari penelitian penulis mengenai pemberitaan media massa Inggris berdasarkan data yang telah diperoleh dari website Lexus.net dan diolah dengan menggunakan aplikasi wordsmith, sebanyak 405 artikel dikumpulkan dalam periode Januari-Mei diperoleh kategori tema dari artikel yang diterbitkan The Guardian sebagai berikut: 


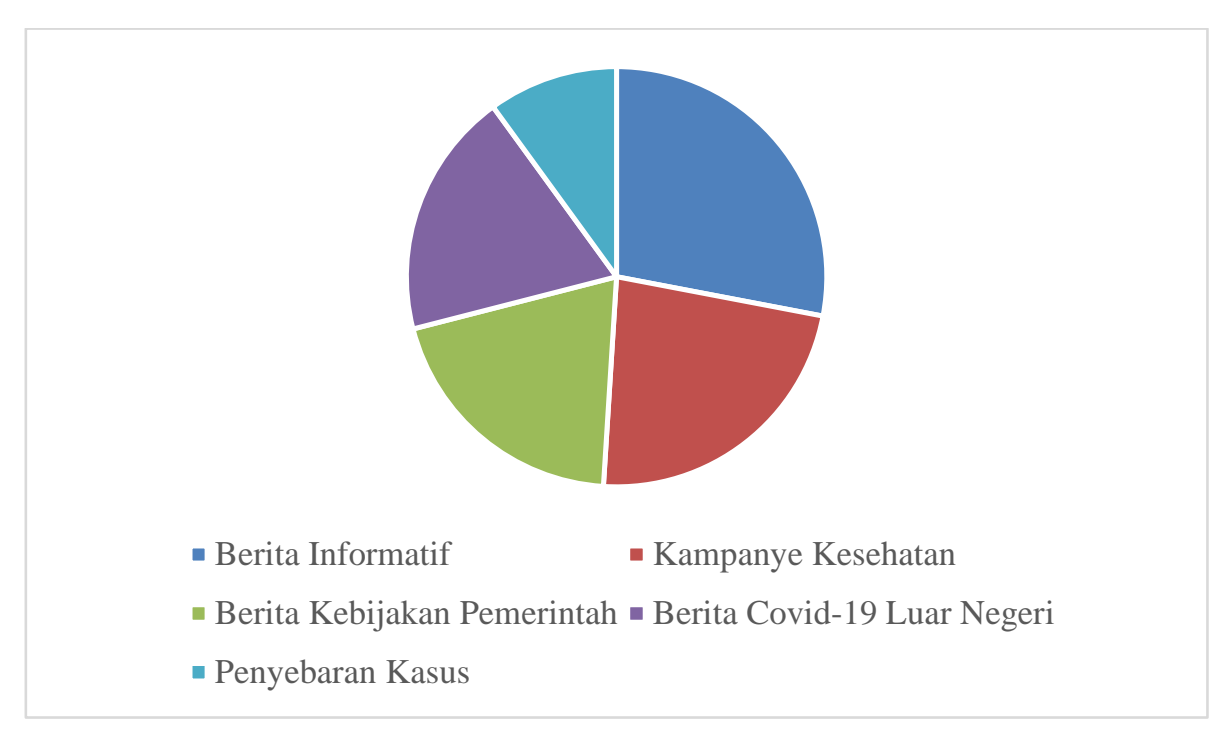

Gambar 2. Tema Pemberitaan COVID-19 The Guardian

Informasi mengenai COVID-19 di The Guardian didominasi oleh pemberitaan informatif mengenai COVID-19. Berita informatif berisikan data-data dan infomasi medis seputar krisis kesehatan yang terjadi di dunia akibat pandemi COVID-19. Artikel-artikel tersebut mendefinisikan masalah yang terjadi, menjelaskan informasi asal-usul COVID-19. Media juga membuat narasi mengenalkan virus Corona kepada masyarakat, mulai dari penyebab penyakit, apa saja gejala jika tertular virus tersebut, sampai dengan rekomendasi perawatan. Di awal pandemi upaya-upaya surat kabar digital dalam mengedukasi masyarakat untuk menginformasikan karakteristik, definisi masalah dan dampak penyebaran virus dan pencegahan telah terdeteksi. Artikel-artikel tersebut membantu masyarakat untuk menyadari krisis kesehatan yang terjadi dan membuat masyarakat waspada akan kesehatan mereka agar tidak tertular COVID-19. Dalam tinjauan penulis artikel-artikel tersebut juga bersumber dari lembaga kesehatan seperti WHO dan The Centers for Disease Control and Prevention (CDC). Sumber dari lembaga kesehatan sangat penting dalam meningkatkan kredibilitas berita terutama karena subjeknya sangat relevan dengan atau masalah ilmiah.

The Guardian juga secara spesifik membuat kolom khusus Coronavirus Outbreak dan kolom khusus seputar pandemi COVID-19. Informasi kesehatan dan medis mengenai virus Corona dijabarkan dalam kolom explainer yang terdapat di dalam kolom Coronavirus Outbreak. Pembuatan kolom mengenai informasi medis seputar virus Corona menandai urgensi pandemi yang terjadi. Sebagai media massa yang dapat menjangkau masyarakat luas, edukasi mengenai pandemi bisa lebih efektif diberikan kepada masyarakat. Pengkategorian kolom pun dapat memudahkan pembaca The Guardian dalam mengakses informasi medis ter-update seputar virus Corona. Tema ini menjadi evaluasi moral bagi masyarakat dan menjadikan umpan positif kepada pemerintah Inggris untuk menanggapi krisis yang terjadi dan membuat keputusan dalam menangani krisis kesehatan yang terjadi. 
Tabel 1. Artikel Medis Mengenai COVID-19 The Guardian

\begin{tabular}{lll}
\hline No & Tanggal & Judul \\
\hline 1. & $7 / 02 / 2020$ & Who is most at risk of contracting COVID-19? \\
2. & $2 / 03 / 2020$ & How to protect yourself against corona virus? \\
3. & $3 / 03 / 2020$ & $\begin{array}{l}\text { Super Spreaders: what are they and how are they transmiting } \\
\text { corona virus? }\end{array}$ \\
\hline
\end{tabular}

\section{Sumber: The Guardian}

Kategori kedua yang dominan dalam pemberitaan The Guardian adalah kampanye kesehatan. Contoh-contoh artikelnya berisikan protokol kesehatan yang harus dilakukan masyarakat selama pandemi. Artikel-artikel yang diterbitkan adalah mengenai informasi anjuran sosial distancing, larangan bepergian, dan anjuran untuk tetap di rumah. The Guardian juga memberitakan tentang lockdown yang terjadi di China dan membandingkan dengan kondisi yang terjadi di Inggris. Perdana Menteri Inggris Boris Johnson sempat memunculkan kontroversi dalam penanganan pandemi COVID-19 di Inggris. Dia mengatakan Inggris akan menerapkan herd imunity dalam penanganan pandemi COVID-19. Terbukti di awal pandemi, Inggris hanya menerapkan anjuran untuk tetap di rumah dan masyarakat tidak diperbolehkan keluar jika tidak berkepentingan.

Namun seiring pemberitaan media massa yang mendominasi anjuran lockdown pada 23 Maret 2020, Inggris resmi menerapkan lockdown. Boris Johnson mengambil kebijakan pembatasan wilayah atau lockdown, serta memerintahkan warganya tinggal di rumah untuk menghentikan penyebaran virus Corona. Kebijakan itu juga mengharuskan semua toko untuk tutup, perkantoran menerapkan kebijakan work from home dan memperingatkan bahwa masyarakat yang tidak mengikuti aturan akan menghadapi denda (Gov UK, 2020).

Johnson juga diberitakan menerapkan peraturan bahwa masyarakat Inggris hanya diizinkan meninggalkan rumah mereka untuk berolahraga, berbelanja kebutuhan dasar, membeli kebutuhan medis, menyediakan perawatan untuk orang lain, atau melakukan perjalanan ke dan dari tempat kerja dengan menerapkan protokol physical distancing (Gov UK, 2020). Berita-berita seputar kebijakan pemerintah dalam menangani penyebaran pandemi masuk kedalam kategori berita tentang kebijakan pemerintah. Pengumumanpengumuman pemerintah dari kemungkinan penerapan lockdown sampai terjadinya lockdown, menganjurkan pekerja untuk work from home, kebijakan tracing dan tracking, dan kebijakan setiap negara bagian dalam mengatasi pandemi dimasukan dalam kategori ini. Upaya pemerintah dengan bantuan media massa mengumumkan kebijakan-kebijakan tersebut dapat mengurangi penyebaran pandemi, contohnya kontrol perbatasan internasional dengan melarang penerbangan dari dan ke wilayah Inggris terhadap negara yang terkena wabah COVID-19. Efek langsung dari hal ini adalah arahan kesehatan masyarakat yang mengurangi jumlah wisatawan dan membatasi siswa internasional untuk memasuki Inggris.

Kategori ketiga adalah berita tentang penyebaran kasus. Update tentang jumlah kasus setiap harinya, dan jumlah kematian yang terjadi. Berita ini tak hanya memuat kasus positif dan juga kematian di Inggris, tetapi juga berita-berita mengenai penambahan kasus di luar Inggris. Berita-berita kematian ini dapat mengontrol dan memainkan peran kunci dalam menyarankan agar pemerintah Inggris waspada akan bahaya virus Corona. Terbukti dalam 
tahap pertama muncul sampai dengan kurva melandai, berita kematian dan grafik kasus COVID-19 yang terjadi di Inggris bisa mengubah arah kebijakan pemerintah mengenai penanganan kasus COVID-19. Pada tahap outbreak terjadi pemerintah Inggris langsung menerapkan lockdown, tapi seiring menurunnya kasus di bulan Juni 2020, Inggris resmi melonggarkan lockdown, masyarakat bisa kembali beraktivitas ke luar rumah meskipun harus tetap menerapkan protokol kesehatan.

Kategori keempat adalah berita ekonomi. Penutupan perbatasan dan berhentinya aktivitas masyarakat menimbulkan dampak ekonomi secara signifikan. Penerapan lockdown dan penutupan tempat hiburan serta larangan berpergian menimbulkan dampak negatif bagi perekonomian Inggris. Hal ini juga menjadi dominan di dalam pemberitaan media massa. Berita mengenai kacaunya pasar keuangan dan ekonomi global masuk dalam kategori ini, banyaknya perusahaan yang mengalami penurunan pendapatan juga masuk ke dalam kategori ini, selain itu juga risiko terkait resesi yang akan melanda negara-negara dunia. Pada tahap awal pandemi respons kesehatan masyarakat disorot oleh media massa Inggris dengan menekankan pada perubahan perilaku masyarakat mengenai krisis kesehatan yang terjadi. Seiring berjalannya waktu The Guardian juga menerbitkan artikel-artikel mengenai risiko dampak ekonomi yang terjadi, sehingga artikel-artikel yang terbit kemudian menyoroti masalah ekonomi. Narasi-narasi berita seputar ekonomi memiliki dampak langsung bagi pemerintah dalam menerapkan kebijakan bantuan ekonomi dan stimulus keuangan.

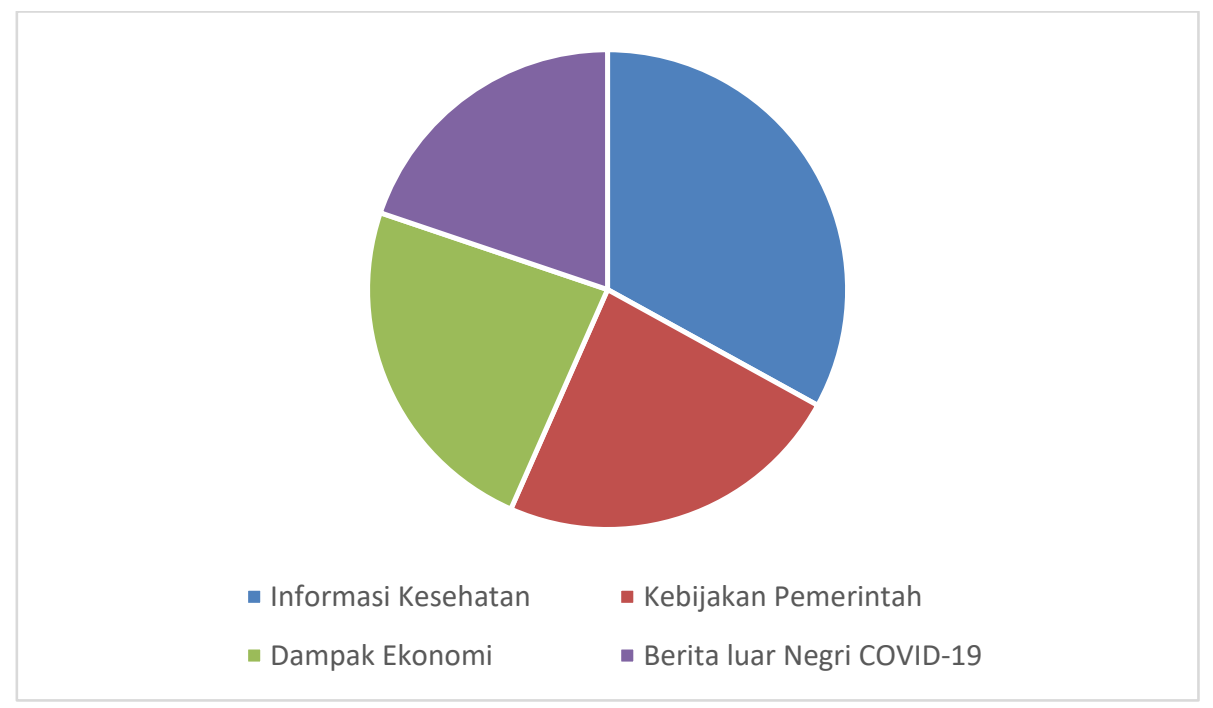

Gambar 3. Tema Pemberitaan COVID-19 di BBC

Data di atas merupakan hasil olah data penulis dalam meneliti artikel informasi dominan mengenai COVID-19 di BBC, sebanyak 367 artikel dikumpulkan sehingga memunculkan kategori di atas. Pemberitaan pada BBC didominasi dengan pemberitaan seputar informasi medis mengenai COVID-19, baik berupa artikel penanganan ter-update COVID-19, update mengenai grafik kasus COVID-19 dan imbauan kepada masyarakat untuk menerapkan protokol kesehatan. BBC memiliki kolom khusus yang membahas tentang Coronavirus, dan informasi kesehatan mengenai Coronavirus atau COVID-19 masuk ke dalam sub kolom explainer, video explainer, dan reality check. Sub kolom tersebut langsung muncul dan tersedia pada laman awal kolom Coronavirus, sehingga masyarakat 
bisa mengakses langsung berita informasi medis mengenai corona dengan mudah. Kemunculan virus Corona di Inggris membuat BBC menekankan risiko berbahaya Covid-19 ini dengan menerbitkan artikel dengan judul sebagai berikut:

Tabel 2. Artikel Medis Mengenai COVID-19 di BBC

\begin{tabular}{ll}
\hline No & Judul Berita \\
\hline 1. & IMPACT: What the virus does to the body? \\
2. & RECOVERY: How long does it take? \\
3. & LOCKDOWN: How can we lift restrictions? \\
& ENDGAME: How do we get out of this mess? \\
\hline
\end{tabular}

\section{Sumber: BBC.com}

Informasi seputar COVID-19 di atas muncul di setiap laman berita tentang COVID-19. Sumber berita tersebut didapatkan dari lembaga kesehatan seperti WHO, CDC, dan peneliti, artikel tersebut oleh editorial BBC dan di-update setiap ada perkembangan dan penemuanpenemuan terbaru mengenai COVID-19. BBC juga membuat kolom khusus Coronavirus dalam situs webnya untuk memudahkan pembaca yang ingin mengakses informasi seputar pandemi, bisa langsung meng-klik kolom tersebut sehingga muncullah semua berita yang berhubungan dengan virus Corona. Perdana Menteri Inggris Boris Johnson juga ditulis saat memunculkan kontroversi dalam penanganan wabah COVID-19 di Inggris. Johnson mengatakan Inggris akan menerapkan herd imunity dalam penanganan wabah COVID-19. Namun setelah Johnson dinyatakan terkonfirmasi COVID-19 pada akhir Maret 2020, arah kebijakan Inggris mengenai herd imunity diubah.

BBC terus memberitakan perkembangan kesehatan Johnson yang terkonfirmasi positif COVID-19 dan dirawat di rumah sakit. Dampak ekonomi menjadi dominan pemberitaan sama seperti The Guardian, kemudian kategori yang terakhir BBC menyoroti berita seputar perkembangan COVID-19 di luar negeri. Hal ini penting untuk menyoroti dan mengawasi langkah-langkah kebijakan yang diambil oleh pemerintah Inggris dalam menangani pandemi, terutama berita mengenai arah kebijakan negara-negara lain dalam menangani pandemi sehingga ada pembanding bagi pemerintah Inggris dalam mengatasi pandemi COVID-19.

Selanjutnya, Jerman menjadi negara ketiga terbesar kasus positif dengan jumlah 139.897 jiwa namun memiliki jumlah kematian dengan presentasi yang kecil sebesar 4.294 jiwa. Jerman mengambil kebijakan menutup sekolah dan melarang pertemuan. Sejak Januari berita di Jerman memfokuskan dampak pandemi terhadap ekonomi, selain berita tentang kemungkinan lockdown sudah dinarasikan oleh media massa pada tahap awal pandemi (Duyen Tran, 2020). Tindakan yang cepat dibandingkan dengan negara-negara lain untuk menghentikan penyebaran COVID-19. Pertengahan Maret 2020, 16 negara Jerman tanpa menunggu protokol dari pusat telah melakukan lockdown. 


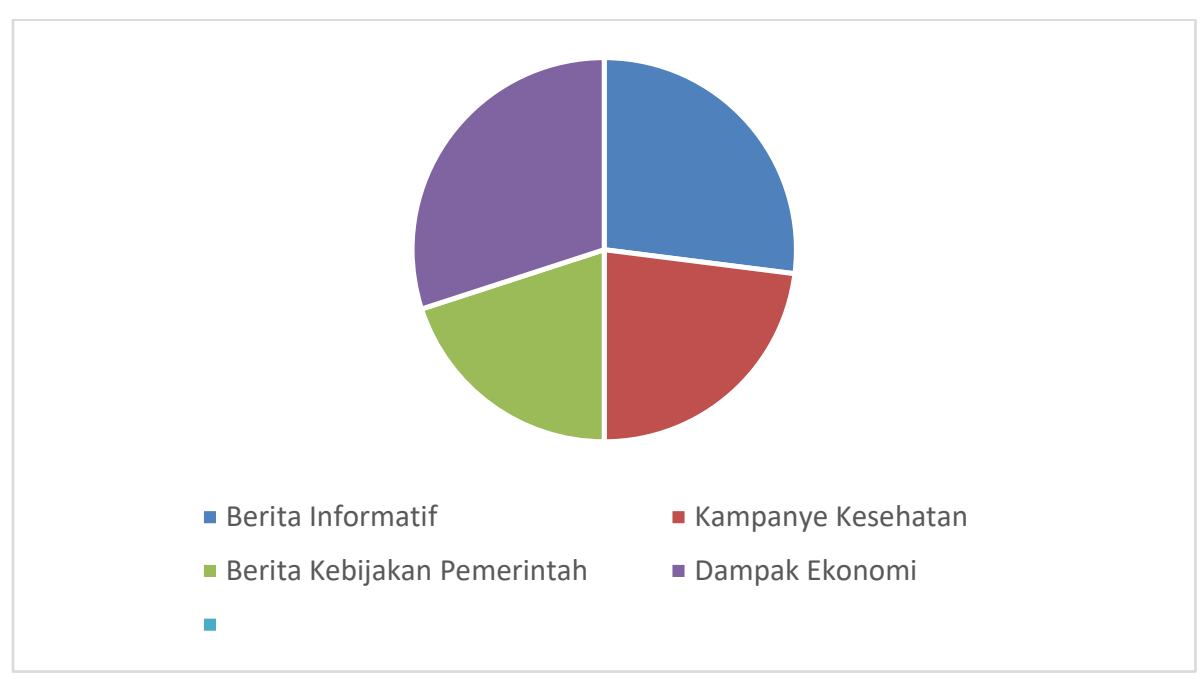

Gambar 4. Tema Pemberitaan COVID-19 di DW

Grafik di atas merupakan kategori tema berita yang diterbitkan di awal pandemi COVID-19 muncul di Jerman, total 300 artikel dikumpulkan dalam periode Januari-Mei 2020. Pemberitaan media massa yang dominan pada tahap awal adalah kemungkinan lockdown dan dampak ekonomi yang terjadi akibat COVID-19. DW menerbitkan artikelartikel yang berfokus terhadap dampak ekonomi yang diprediksi akan terjadi jika pemerintah Jerman melakukan lockdown seperti China. Hal ini menimbulkan arah kebijakan pemerintah Jerman yang sangat masif untuk melakukan tracing dan tracking di awal pandemi muncul untuk mendeteksi masyarakat yang berpotensi terkena virus Corona. Contoh berita, pada 27 Februari 2020, DW menerbitkan artikel berjudul Coronavirus outbreak hitting German supply chains with fears of economic paralysis.

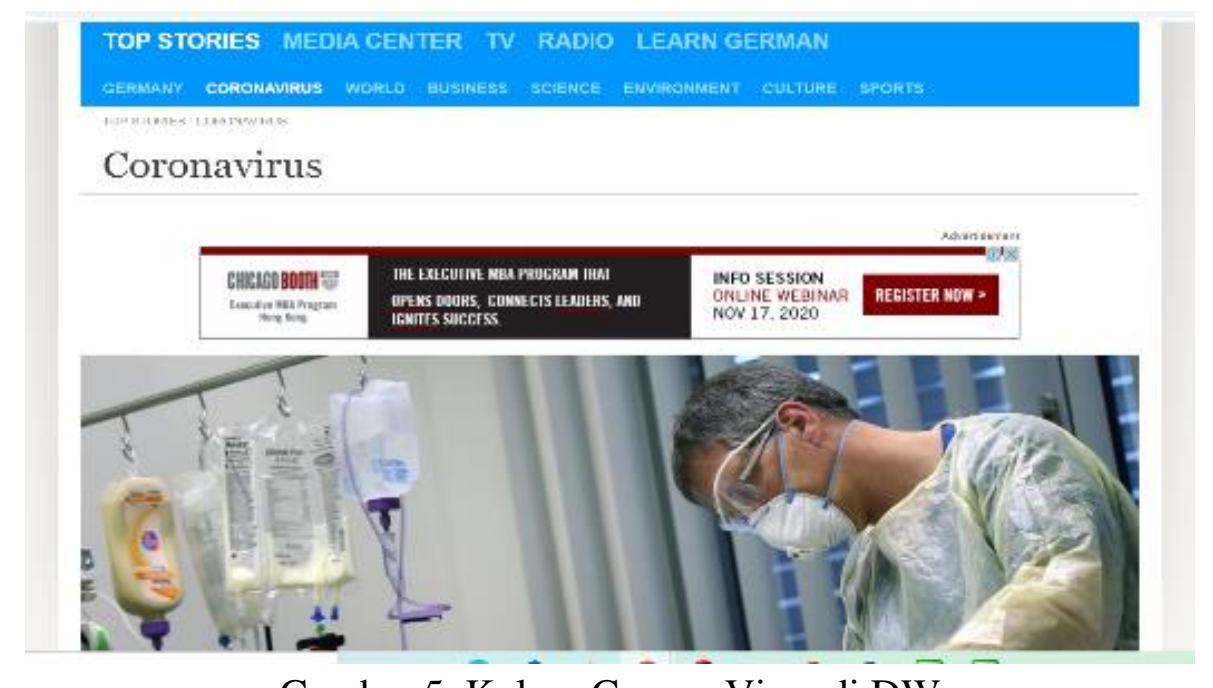

Gambar 5. Kolom Corona Virus di DW

Kemudian dominasi berita disusul informasi mengenai seputar COVID-19, tindakan pencegahan dan kampanye mengenai protokol kesehatan. DW membuat kolom khusus informasi mengenai Coronavirus. Dalam sub kolom Coronavirus berita mengenai pandemi tersebut dikelompokan dalam beberapa kategori yakni sub kolom: (1). Coronavirus in 
Germany; (2). Coronavirus Around the World;(3). The Science Behind COVID-19. Pada kolom The Science Behind COVID-19 DW menerbitkan artikel-artikel seputar kesehatan mengenai COVID-19 dan mengkampanyekan protokol kesehatan. Selain itu DW juga menerbitkan artikel yang membantu memberantas hoaks yang beredar pada masyarakat seputar COVID-19. Sub kolom ini berisikan data-data informasi mengenai COVID-19 dan misinformasi yang beredar mengenai COVID-19, serta kampanye mengenai protokol kesehatan yang bersumber dari lembaga kesehatan CDC dan WHO.

DW juga mempunyai fitur khusus yakni newsletter informasi seputar COVID-19. Pembaca DW bisa mendapatkan informasi seputar COVID-19 dengan mendaftarkan nama dan e-mail. Informasi seputar COVID-19 akan dikirimkan secara langsung kepada pembaca yang sudah mendaftarkan diri.

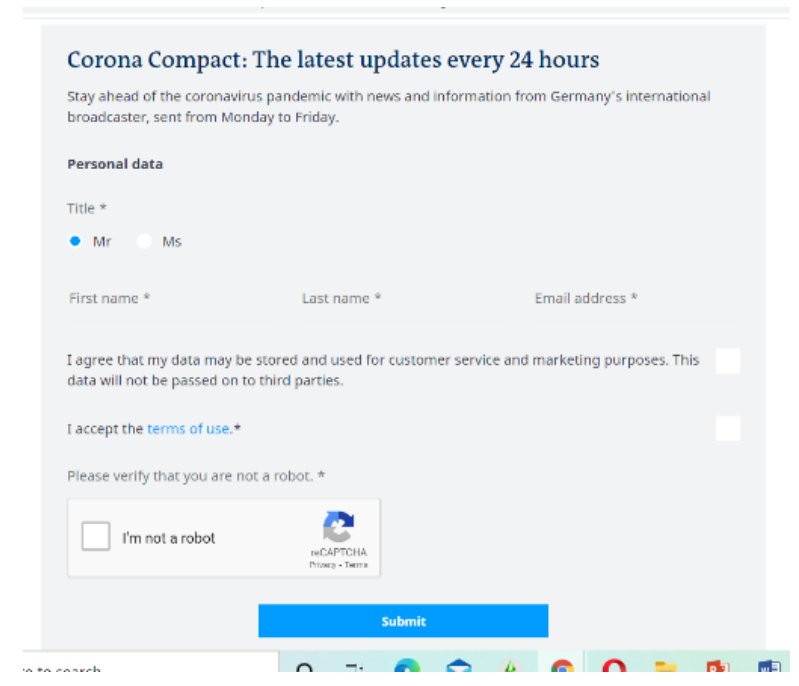

Gambar 6. Newsletter COVID-19 di DW

Semakin bertambahnya kasus di Jerman di bulan Maret 2020, frekuensi pemberitaan mengenai COVID-19 meningkat dalam pemberitaan. Total terdapat 468 artikel dalam kurun waktu 1-30 Maret 2020, sebagian besar artikel didominasi berita tentang anjuran untuk tetap berada di rumah dan menjaga jarak. Jerman mulai melakukan lockdown terhitung 22 Maret 2020. Sosialisasi mengenai tracing dan tracking bagi masyarakat yang berkontak langsung dengan orang yang positif COVID-19 mendominasi pemberitaan di bulan Maret, disusul oleh pemberitaan tentang langkah-langkah pemerintah Jerman yang sudah menyiapkan fasilitas kesehatan yang mendukung untuk menampung pasien COVID-19. Namun beritaberita ekonomi juga masih memenuhi pemberitaan media, mulai dari kerja sama antara Jerman-China dalam pengadaan alat kesehatan dan paket stimulus ekonomi akibat dari penutupan perbatasan dan larangan memasuki Jerman serta penutupan beberapa sektor industri yang mengakibatkan ekonomi terhambat.

Media massa kedua yang diteliti adalah Bild. Seperti DW, Bild juga mempunyai kolom khusus informasi seputar COVID-19 di halaman website-nya. Terdapat dua sub kolom dalam website Bild, yang pertama Bild membuat laman khusus berjudul Virus Radar. Sub kolom ini berisikan peta perkembangan informasi mengenai COVID-19 di Jerman, berisikan sebaran wilayah per negara bagian dan data mengenai jumlah kasus yang 
terkonfirmasi dan jumlah kematian. Setiap waktunya laman ini terus ter-update seiring bertambahnya jumlah kasus dan kematian.

Sub kolom kedua yakni berjudul All Information. Dalam kolom tersebut semua informasi mengenai COVID-19 diterbitkan, kemudian Bild membaginya menjadi beberapa kategori seperti informasi medis atau protokol kesehatan seputar COVID-19, pemberitaan mengenai penanganan COVID-19 di Jerman dan update mengenai COVID-19 di beberapa kota besar di Jerman. Artikel-artikel tersebut masuk ke dalam kategori berita informatif mengenai COVID-19. Narasi yang dibangun dalam artikel-artikel tersebut menimbulkan dampak perubahan perilaku sosial masyarakat Jerman dalam situasi pandemi. Kategori ini menjadi yang dominan dalam pemberitaan mengenai COVID-19 di Bild.

Berdasarkan data yang diperoleh dari pengamatan penulis dengan sampel 211 artikel yang diambil dari periode Januari-Mei 2020 dalam kolom Coronavirus pemberitaan dominan mengenai COVID-19 sebagai berikut:

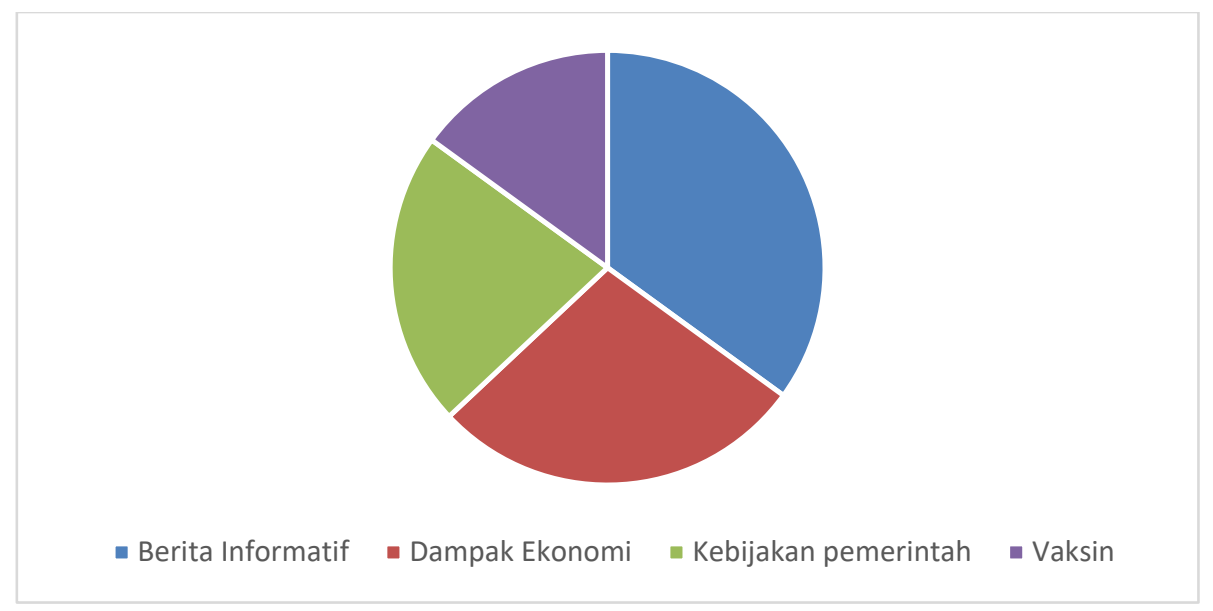

Gambar 7. Tema Pemberitaan COVID-19 di Bild

Kategori pertama adalah berita informatif. Artikel tersebut berisikan informasi mengenai COVID-19 yang bersumber dari lembaga CDC dan WHO, sebagian artikel diperbaharui seiring dengan informasi-informasi dari lembaga kesehatan WHO yang terbaru. Artikel yang dipublikasikan berupa informasi seputar protokol kesehatan, gejala-gejala virus Corona, kampanye untuk selalu menjaga jarak, dan penggunaan masker di area publik. Artikel mengenai ekonomi sebagian besar membahas tentang perekonomian yang terkena dampak COVID-19.

Kategori kedua adalah berita ekonomi. Prediksi-presiksi mengenai perekonomian dunia dibangun dalam narasi-narasi berita yang diterbitkan oleh Bild. Bingkai konsekuensi ekonomi mengenai pandemi dihadirkan dalam sudut pandang keuangan individu, kelompok, institusi, wilayah, atau negara pada tahap awal COVID-19 muncul di Jerman. Kategori ketiga adalah berita mengenai kebijakan pemerintah. Pemerintah Jerman pada masa awal pandemi dinarasikan telah sigap mempersiapkan ketersediaan rumah sakit dan tenaga medis. Kerja sama antara Jerman dan China disoroti dalam kategori ekonomi sebagai langkah menangani pandemi COVID-19 di Jerman. Kategori terakhir adalah vaksin. Sejak April 
2020, Jerman telah mengembangkan vaksin untuk mencegah COVID-19, tema ini pun menjadi sorotan pada laman COVID-19 dan Bild terus meng-update perkembangan terbaru mengenai vaksin yang dikembangkan oleh pemerintah Jerman. Berita mengenai vaksin memunculkan harapan bagi masyarakat dalam menghadapi situasi pandemi yang terjadi.

Pemberitaan yang intens mengenai virus Corona memenuhi ruang publik termasuk media arus utama Inggris dan Jerman. Informasi terhadap bahayanya virus corona dimunculkan oleh media massa Inggris baik The Guardian maupun BBC, berita mengenai corona bahkan dimunculkan di kolom khusus berisikan informasi mengenai update Corona baik dari dalam dan luar negeri dalam kedua media tersebut. Meskipun saat ini peran media sosial semakin meningkat, termasuk potensinya untuk meningkatkan kesadaran situasi, liputan media surat kabar online saat ini tetap penting dalam pembingkaian debat publik dan kebijakan tentang keamanan terhadap ancaman pandemi di Inggris dan di Jerman.

Berdasarkan pengamatan, The Guardian sangat gencar menekankan pemberitaan bahayanya virus Corona di masa awal pandemi tersebut muncul dengan menerbitkan artikelartikel medis mengenai COVID-19. Dalam beberapa artikel The Guardian membandingkan penanganan corona di Inggris dan luar negeri untuk mengkritisi langkah kebijakan yang diambil oleh pemerintah Inggris dalam menghadapi ancaman virus corona. Penulis berpendapat langkah The Guardian dalam membingkai berita virus corona ini dapat meningkatkan kesadaran publik Inggris akan bahaya virus Corona serta memberikan edukasi berupa informasi rekomendasi penanganan dan pencegahan virus corona kepada publik.

$\mathrm{BBC}$ juga memiliki peran dalam mengedukasi masyarakat mengenai virus Corona dengan bingkai dominan tentang informasi seputar krisis kesehatan dengan menekankan bahaya virus Corona dan langkah-langkah pencegahan agar tidak tertular dari virus Corona. Namun keduanya sama-sama membuat pembingkaian yang menekankan bahayanya virus Corona. Berita dari media massa ini juga menjadikan kontrol pada ruang publik mengenai darurat kesehatan yang terjadi di Inggris akibat pandemi COVID-19 sehingga menjadi referensi bagaimana pemerintah Inggris menerapkan kebijakan menghadapi ancaman virus corona.

Sementara kedua media Jerman pada awal kemunculan COVID-19 pemberitaan media dominan kepada isu ekonomi yang akan menjadi dampak dari penyebaran virus corona. Artikel-artikel yang terbit umumnya berisikan dampak ekonomi dari pandemi dan rekomendasi untuk paket stimulus ekonomi, bantuan maupun subsidi. Kedua media juga melaporkan berita tentang krisis kesehatan yang terjadi di luar Jerman sebagai pembanding dengan kondisi yang terjadi di Jerman. Kemudian di ikuti pengobatan dan solusi untuk menekan penyebaran COVID-19 di Jerman. Pada awalnya, respons mengenai krisis kesehatan disorot dengan contoh yang menekankan penutupan perbatasan atau lockdown yang dilakukan oleh China, serta melarang perjalanan untuk warga Jerman, kemudian dilanjutkan tentang informasi seputar penanganan COVID-19 dan langkah-langkah yang ditujukan kepada individu untuk melakukan protokol kesehatan yang ditetapkan oleh lembaga kesehatan baik dari WHO maupun CDC.

Penelitian ini menunjukan bahwa media massa Jerman melaporkan pandemi COVID19 memiliki peran terhadap pelaporan berita COVID-19 dengan objektif dengan menekankan pada konsekuensi terjadinya pandemi dan membandingkannya dengan krisis 
yang terjadi di negara-negara lain, sebagai metode untuk memahami krisis kesehatan yang terjadi, dampaknya pemerintah Jerman kemudian lebih sigap dalam hal tracing dan tracking dalam menekan penyebaran laju pandemi, untuk mencegah dampak yang lebih buruk terjadi pada kondisi perekonomian.

Hasilnya, Jerman menjadi negara ketiga terbesar kasus positif dengan jumlah 139.897 jiwa namun memiliki jumlah kematian dengan presentasi yang kecil sebesar 4.294 jiwa. Sejak Januari 2020 media berita di Jerman memfokuskan dampak pandemi terhadap ekonomi, selain berita tentang kemungkinan lockdown sudah di narasikan oleh media massa pada tahap awal pandemi (Duyen Tran, 2020). Sebuah tindakan yang cepat dibandingkan dengan negara-negara lain untuk menghentikan penyebaran Covid-19. Pertengahan Maret 2020, 16 negara bagian Jerman tanpa menunggu protokol dari pusat telah melakukan lockdown.

\section{PENUTUP}

Media massa Inggris dan Jerman memiliki peranan untuk menekan laju penyebaran pandemi COVID-19 di masing-masing negaranya melalui bingkai yang berbeda. Kedua media tersebut telah menjalankan peranannya sebagai pers yang bertanggung jawab kepada masyarakat, memberi tahu publik dengan benar dengan menanggapi kebutuhan serta kepentingan masyarakat saat darurat pandemi COVID-19. Temuan penelitian ini adalah terdapat perbedaan bingkai dominan pemberitaan media massa Inggris dan Jerman. Media Inggris lebih menekankan perubahan perilaku sosial masyarakat dalam menangani pandemi COVID-19 dengan dominasi artikel-artikel mengenai protokol kesehatan dan artikel medis. Sedangkan media Jerman lebih menekankan dampak pandemi terhadap perekonomian negara dan dampak kesehatan akibat pandemi COVID-19 dalam pemberitaannya.

\section{REFERENSI}

Abraham, T. (2007). Twenty-First Century Plague: The Story of SARS. Baltimore, MD: John Hopkins University Press.

Andersson, G., Lundstrom, T., Bernier, A., Bjornstrom, E. E. S., Kaufman, R. L., Peterson, R. D., Slater, M. D., Chiricos, T., Eschholz, S., Dixon, T. L., Azocar, C. L., Casas, M., Dorfman, L., Dorfman, L., Schiraldi, V., Schiraldi, V., Esbensen, F.-A., Tusinski, K., Goodman, S., ... Petley, J. (2002). McQuail's Mass Communication Theory. Youth \& Society, 28(1), 498-523.

Dominick, J. R. (2009). The dynamics of mass communication: Media in the digital age. Tata McGraw-Hill Education.

Entman, R (2007) Framing bias: Media in the distribution of power. Journal of Communication 57: 163-173.

Entman, R .(1993). Framing: Toward clarification of a fractured paradigm. Journal of Communication 43(4): 51-58.

Fletcher, R., \& Jenkins, J. (2019). Polarisation and the news media in Europe|Reuters Institute for the Study of Journalism (Issue March). https://reutersinstitute.politics.ox.ac.uk/our-research/polarisation-and-news-mediaeurope 
Hallin, D. C., \& Mancini, P. (2004). Comparing Media Systems: Three Models of Media and Politics. Cambridge, UK: Cambridge

Leach, M., \& Dry, S. (2010). Epidemics: Science, governance, and social justice. In Epidemics: Science, Governance and Social Justice (Issue June). https://doi.org/10.4324/9781849776424

Mahase, E. (2020). Covid-19: UK starts social distancing after new model points to 260000 potential deaths. BMJ (Clinical Research Ed.), 368(March), m1089. https://doi.org/10.1136/bmj.m1089

Okunna, C. S. \& Omenugha, K. A. (2012). Introduction to mass communication (3rd ed.). Enugu: New Generation Books.

Pieri, E. (2019). Media Framing and the Threat of Global Pandemics: The Ebola Crisis in UK Media and Policy Response. Sociological Research Online, 24(1), 73-92. https://doi.org/10.1177/1360780418811966

Siebert, Fred. S; Theodore, Peterson; Schramm, Wilbur. (1963). Four Theories of The Press: The Authotarian, Libertarian, Social Responsibility, and Soviet Communist Concept of What the Press Should Be and Do. Chicago: University of Illinois Press

Stafford, N. (2020). Covid-19: Why Germany's case fatality rate seems so low. The BMJ, 369(April), 5-6. https://doi.org/10.1136/bmj.m1395

World Health Organization. (2020). Covid-19 Situation Report. World Health Organization, 31(2), 61-66.

Zhou, W., Wang, A., Xia, F., Xiao, Y., \& Tang, S. (2020). Effects of media reporting on mitigating spread of COVID-19 in the early phase of the outbreak. Mathematical Biosciences and Engineering, 17(3), 2693-2707. https://doi.org/10.3934/mbe.2020147 